\title{
RESEARCH PROJECT
}

\section{LANGUAGE AND DISCOURSE PRACTICES OF WORLD MEDIA IN THE CONTEXT OF AXIOLOGICAL DOMINANTS' CHANGE}

\author{
Golubovska Iryna, igolubovska777@gmail.com \\ Doctor of Science, Full prof. \\ Taras Shevchenko National University of Kyiv, \\ Institute of Philology
}
Darchuk Natalia, nataliadarchuk@gmail.com
Doctor of Science, Full prof.
Taras Shevchenko National University of Kyiv, Institute of Philology

\section{Chernenko Hanna, hanna.chernenko@gmail.com \\ Ph.D., Associate prof. \\ Taras Shevchenko National University of Kyiv, \\ Institute of Philology}

The main problem the present project addresses is the development of an integrated approach to diachronically oriented study of the main sociocultural values based on semiotic oppositions: culture / nature; materialistic / spiritual; joy / grief; health / illness; beauty / deformity, which involves the development of linguocognitive and linguoculturological methods on the material of fine arts' and media texts based on the identification of verbal and non-verbal markers of value dominants what contributes to the formation of a postmodernist model of the world examined in the veine of new cultural values and anti-values emergence.

The working hypothesis of the project is that the study of lingual and discursive reflexes of the changes in values of the modern society, made with the help of corpus data on the material of the European languages, will reveal the main features of the modern world conceptual system based on the common for many ethnic groups (at least European) systems of values and anti-values.

The goal of the project might be put as working out of an algorithm for analyzing the process of changing of axiological orientations of a society, which will be carried out on the material of fiction and media texts on the grounds of a corpus-based approach to the processing language data.

The relevance of such a research is due to the lack of systemic studies of this kind both in domestic linguistics and abroad: so far there are no studies within which an attempt is made to investigate changes in the axiosphere of modern society on the

Дослідницький проект [Исследовательский проект]

(С) Голубовська І. О., Дарчук Н. П., Черненко А. А. [Голубовская И. А., Дарчук Н. П., Черненко А. А.], igolubovska777@gmail.com,nataliadarchuk@gmail.com, hanna.chernenko@gmail.com Мова і дискурсивні практики світового медіапростору у контексті змін аксіологічних домінант [Язык и дискурсивные практики мирового медиапространства в контексте изменений аксиологических доминант] (Українською / На укр. яз) 
material of many European languages practicing the corpus approach to processing cultural and speech data and highlightening both global and national-specific values inherent for this or that linguoculture.

The study will be anthropocentrically oriented, as well as a set of neolinguistic approaches to processing lexical, phraseological and grammatical innovations in media (which will be considered in linguocognitive, linguo cultural, linguopragmatic, discursive and suggestive aspects) would be exercised.

Predicted results might significantly affect the empowerment of human selfreflection in the context of identifying axiological attitudes that speakers both intentionally and unwittingly broadcast in their daily communicative practices (many of them are being formed just by media and fiction texts). This is extremely important in the context of the informational wars, when there is a need to increase the level of mass media texts' critical perception, the last very often appear to be an instrument of political propaganda.

\section{ИССЛЕДОВАТЕЛЬСКИЙ ПРОЕКТ}

\section{ЯЗЫК И ДИСКУРСИВНЫЕ ПРАКТИКИ МИРОВОГО МЕДИАПРОСТРАНСТВА В КОНТЕКСТЕ ИЗМЕНЕНИЙ АКСИОЛОГИЧЕСКИХ ДОМИНАНТ}

\section{Голубовская Ирина Александровна, igolubovska777@gmail.com}

д. филол. наук, проф.

Киевский национальный университет имени Тараса Шевченко, Институт филологии

Дарчук Наталья Петровна, nataliadarchuk@gmail.com д. филол. наук, проф.

Киевский национальный университет имени Тараса Шевченко, Институт филологии

Черненко Анна Анатольевна, hanna.chernenko@gmail.com к. филол. наук, доц.

Киевский национальный университет имени Тараса Шевченко Институт филологии

Основная проблема, на разрешение которой будет направлен проект,разработка комплексного подхода к диахронно ангажированному изучению базовых социокультурных ценностей на основе семиотических оппозиций: культура / природа; материальное / духовное; радость / горе; здоровье / болезнь; красота / уродство, который предусматривает разработку методики igolubovska777@gmail.com,nataliadarchuk@gmail.com, hanna.chernenko@gmail.com 
лингвокогнитивного и лингвокультурологического анализа художественных и медиатекстов на основе выделения вербально-невербальных маркеров ценностных доминант, способствующих формированию постмодернистской картины мира в аспекте возникновения новых культурных ценностей и антиценностей.

Рабочая гипотеза проекта будет заключаться в том, что исследование языковых и дискурсивных рефлексов изменений в ценностных установках современного нам общества, сделанное с привлечением корпусных данных на материале языков «среднеевропейского стандарта», обнаружит основные черты новой концептуальной картины мира современности на основе определения общей для многих этносов (по крайней мере европейских) системы ценностей и антиценностей.

Цель проекта можно сформулировать как создание алгоритма анализа процесса изменений аксиологических ориентаций общества, который будет осуществлен на материале художественных и медиатекстов с привлечением корпусного подхода к разработке языковых данных.

Актуальность такого рода исследования обусловлена отсутствием системных исследований такого рода как в отечественной лингвистике, так и за рубежом, поскольку пока не существует исследований, в рамках которых была бы предпринята попытка исследовать изменения в аксиосфере современного общества на материале многих европейских языков с привлечением корпусного подхода к обработке культурно-речевых данных и выделения при этом как глобальных, так и национально-специфических ценностей, присущих отдельным лингвокультурам.

В основу этого исследования будет положен антропоцентрический подход, а также комплекс неолингвистических подходов к толкованию лексико-фразеологических и лексико-грамматических инноваций в медиа, которые будут рассматриваться в лингвокогнитивном, лингвокультурологическом, лингвопрагматическом, дискурсивном, суггестивном аспектах.

Прогнозируемые результаты могут существенно повлиять на расширение возможностей саморефлексии человека в контексте выявления аксиологических установок, которые говорящие умышленно или невольно транслируют в своей повседневной коммуникации (многие из них формируют именно медиа- и художественные тексты). Это крайне важно в условиях информационной, консциентальной войны, когда существует потребность в повышении уровня критического восприятия массмедийных текстов, которые очень часто выступают орудием политической пропаганды.

Дослідницький проект [Исследовательский проект] (ㄱ Голубовська І. О., Дарчук Н. П., Черненко А. А. [Голубовская И. А., Дарчук Н. П., Черненко А. А.], igolubovska777@gmail.com,nataliadarchuk@gmail.com, hanna.chernenko@gmail.com Мова і дискурсивні практики світового медіапростору у контексті змін аксіологічних домінант [Язык и дискурсивные практики мирового медиапространства в контексте изменений аксиологических доминант] (Українською / На укр. яз) 


\section{ДОСЛІДНИЦЬКИЙ ПРОЕКТ}

\section{МОВА І ДИСКУРСИВНІ ПРАКТИКИ СВІТОВОГО МЕДІАПРОСТОРУ У КОНТЕКСТІ ЗМІН АКСІОЛОГІЧНИХ ДОМІНАНТ}

Голубовська Ірина Олександрівна, igolubovska777@gmail.com

д. філол. наук, проф.

Київський національний університет імені Тараса Шевченка, Інститут філології

Дарчук Наталія Петрівна, nataliadarchuk@ gmail.com д. філол. наук, проф.

Київський національний університет імені Тараса Шевченка, Інститут філології

\section{Черненко Анна Анатоліївна, hanna.chernenko@gmail.com к. філол. наук, доц. \\ Київський національний університет імені Тараса Шевченка Інститут філології}

Будь-яка нова епоха породжує певний набір життєвих цінностей, які виформовують нову норму міжлюдських стосунків, новий стиль та образ життя, у кінцевому рахунку - нові світоспоглядальні соціально заангажовані орієнтири людського буття. Сучасна епоха постмодерну тут i зараз визначає особливий характер життєвих цінностей, вносить суттєві коректури в їх ієрархію і змістове наповнення. При цьому художній дискурс та засоби масової інформації - 3MI, які у новому постіндустріальному суспільстві стають універсальною формою отримання знання про соціально-політичне життя глобалізованого суспільства, пропонують певну ієрархію ціннісних смислів, нові психоповедінкові моделі, тим самим суттєво впливаючи на трансформацію аксіологічної сфери того чи того соціуму. При цьому нові аксіологічні домінанти далеко не завжди спрямовані на консолідацію суспільства: часто-густо вони набувають руйнівної, деструктивної якості, характеру соціокультурної антицінності. Таким чином, великої значущості у наш карколомний час набуває відстеження змін в аксіологічній сфері 
суспільства на основі вивчення мовних, мовленнєвих та дискурсивних інновацій, що ефективно можна здійснювати із залученням лінгвоінформаційних технологій корпусів мов (зокрема Корпусу української мови, створеного фахівцями КНУ імені Тараса Шевченка під керівництвом професора Наталії Дарчук (www.mova.info), потужного комп'ютерного ресурсу, який надає можливість на основі системи підкорпусів медіатекстів, художньої прози, поезії, наукових текстів проводити лінгвістичну експертизу, у тому числі й відносно змін аксіологічних суспільних орієнтацій.

Основна проблема, на яку буде спрямовано проект, - розроблення комплексного підходу до діахронно заангажованого вивчення базових соціокультурних цінностей на основі семіотичних опозицій: культура/природа; матеріальне/духовне; радість/горе; здоров'я/хвороба; краса/потворність, який передбачає розроблення методики лінгвокогнітивного та лінгвокультурологічного аналізу художніх та медіатекстів на основі виділення вербально-невербальних маркерів ціннісних домінант, що сприяють формуванню постмодерної картини світу в аспекті постання нових культурних цінностей і антицінностей.

Об'єктом такого дослідження можуть виступити медіатексти корпусів мов (української, російської, англійської, французької, німецької, іспанської тощо), а також відповідні художні дискурси XXI століття, розглядувані у контексті представлення змін аксіологічних домінант постмодерного світу. Предметом виступить дослідження особливостей процесу трансформації базових соціокультурних цінностей у постмодерному соціумі, відображені у мовних інноваціях і змінах, у розгортанні та реалізації дискурсивних практик на матеріалі медіа- та художніх текстів української, російської, англійської, французької, німецької мов тощо.

Для реалізації заявленої мети вже створено необхідне підгрунтя. Так, напрацьовано методологію дослідження, а саме: 1) розроблені методи зіставних досліджень мовно-концептуальних систем і аксіологічних домінант у різних лінгвокультурах (І. О. Голубовська, О. Левко), у тому числі в діахронічному вимірі на прикладі окремих концептів (I. О. Голубовська, О. В. Левко, Л. В. Клименко, Г. А. Черненко);

Дослідницький проект [Исследовательский проект] () Голубовська І. О., Дарчук Н. П., Черненко А. А. [Голубовская И. А., Дарчук Н. П., Черненко А. А.], igolubovska777@gmail.com,nataliadarchuk@gmail.com,hanna.chernenko@gmail.com Мова і дискурсивні практики світового медіапростору у контексті змін аксіологічних домінант [Язык и дискурсивные практики мирового медиапространства в контексте изменений аксиологических доминант] (Українською / На укр. яз) 
2) опрацьовано методику опису процесів формування ціннісних концептів (Г. А.Черненко); 3) осмислено фразеологізм як маркер активних соціальних процесів, вербалізованих у масовій свідомості (Д. Ю. Сизонов); 4) досліджено трансформації у мові медіа-, зокрема Інтернет-простору, в умовах інформаційної війни та аксіологічних зрушень, викликаних нею, на матеріалі читацьких коментарів та експертного дискурсу (Л. В. Клименко); 5) розроблена методика викриття персуазивного впливу (метастратегії плюс та мінус) у рамках політичного дискурсу (I. О. Голубовська, Д. Д. Харитонова); 6) доступні он-лайн корпуси європейських мов, які можуть стати надійним інструментом вивчення названих явищ (зокрема Корпус української мови, у рамках якого професор Н. П. Дарчук планує розробити універсальні принципи семантичної параметризації аксіологічно заангажованої лексики). Всі ці напрацювання, будучи інтегрованими в єдиний проект, забезпечать цілісне бачення тенденцій розвитку сучасної мови, представлені у медіапросторі різних мов, який на початку XXI ст. набув принципово нових форм і охоплює практично всі сфери людського буття, відображаючи його аксіологічні виміри і водночас впливаючи на них.

Виконання поставлених завдань передбачає продовження та поглиблення напрацювань світової та української науки в галузі вивчення взаємозв'язку між мовно-когнітивною та аксіосферою на матеріалі медіата художніх текстів. Це, зокрема, доробок представників медіалінгвістики (Д. Перрін, Л. О. Кудрявцева, Л. І. Шевченко та ін.), критичного дискурсаналізу (Р. Водак, Т. ван Дейк, Н. Ферклоу та ін.), у якому продемонстровано можливості філологічного аналізу в площині експлікації ціннісних настанов, що транслюються за допомогою мови та виформовуються iï засобами. Власне мовні аксіологічні структури, які неминуче при цьому оприявнюються, детально було описано в працях Г. фон Врігта, О. А. Івіна, О.М.Вольф, В. М. Телії, Н. Д. Арутюнової, Т. А. Космеди. Здобутки когнітологів (М. М. Болдирєв П. Вайт, Р. Джекендофф, С. А. Жаботинска, Дж. Лакофф, Р. Ленекер, Дж. Мартін тощо) надають можливість перейти на інший - прагматично та соціокультурно заангажований рівень розуміння аксіологічних змін, які презентуються медіатекстами та текстами художньої літератури. 
Дискурсивні вияви цінностей як феноменів лінгвокультури вивчали T. Вельхофф, Ж. Житвогнан, С. Жан-Франсуаз, В. І. Карасик. Спроби каталогізувати цінності робилися від часів античності (Аристотель) до сьогодення (Г. Ласуел, А. Маслоу, Ш. Шварц та ін.). Мовознавці доповнили ці напрацювання культурно маркованими тезаурусами (Л. К. Байрамова， С. Бартмінські, О.І.Бессонова, В. І. Кононенко, Я. Пузиніна та ін.). Однак очевидною $є$ прогалина в дослідженнях динамічних процесів в аксіосфері, реалізованих тими чи тими мовнокогнітивними структурами. $€$ нагальна потреба у створенні дослідницької рамки вивчення тих явищ мови та мовлення, що заангажовані ціннісно: мовне конструювання ідентичності, відстеження факторів іiі змінності (О. Гнатюк, В. М. Кулик, М. Рейзігл, М. Рябчук, Ф. Рібейро та ін.), мова ворожнечі, аксіологічних конфліктів і ширше - консцієнтальних, інформаційних воєн $\quad$ (В. П. Горбулін, Л. Ф. Компанцева, О. С. Снитко, Н. В. Слухай, Г. М. Яворська). Хоча в деяких працях зроблено спроби описати закономірності семантичних змін на рівні аксіології значення (Т. М. Антонченко, С. В. Зубарєв, О.В.Орлова, О. О. Ткаченко та ін.), проте все ще не вистачає дослідницької моделі, яка б надала можливість аналітичного охоплення всіх трансформацій, що пов'язані 3 перетвореннями в системі суспільних аксіологічних домінант та їх рефлексами у вигляді тих чи тих особливостей розвитку мови та мовлення. Саме на цих проблемах, які досі лишаються недостатньо вивченими, планується зосередити дослідницьку увагу, залучивши, чи не вперше, для їх вирішення досягнення світової корпусної лінгвістики.

Постіндустріальна ера інформаційного суспільства зумовила карколомні зміни фактично на всіх ділянках суспільного життя, спричинила появу нової ієрархії цінностей, індукувала формування принципово нової картини світу найновішого часу. Мова як найчутливіший індикатор суспільно-політичних змін закарбовує у своїх лексико-фразеологічних формах i дискурсивних реалізаціях трансформацію старих і появу нових соціокультурних цінностей, які нерозривно пов'язані із виникненням нових смислів людського буття. Сучасні медійні тексти та сучасний художній дискурс, маючи потужний потенціал впливу на людську особистість, фіксують цю нову систему

Дослідницький проект [Исследовательский проект]

() Голубовська І. О., Дарчук Н. П., Черненко А. А. [Голубовская И. А., Дарчук Н. П., Черненко А. А.], igolubovska777@gmail.com,nataliadarchuk@gmail.com,hanna.chernenko@gmail.com Мова і дискурсивні практики світового медіапростору у контексті змін аксіологічних домінант [Язык и дискурсивные практики мирового медиапространства в контексте изменений аксиологических доминант] (Українською / На укр. яз) 
ціннісних смислів. Причому, якщо медіадискурс їі часто-густо нав'язує за допомогою маніпулятивних стратегій і тактик, - у художньому дискурсі відбувається iї рефлексія. Таким чином, виникає нагальна потреба в дослідженні еволюції соціокультурних цінностей, що виступають орієнтирами індивідуального та суспільного життя людини, які можуть бути відстежені на мовно-дискурсивному матеріалі за допомогою віднайдення певних вербально-авербальних маркерів трансформацій і змін у ментальності того чи того етносу.

Робоча гіпотеза такого масштабного проекту полягатиме в тому, що дослідження мовних та дискурсивних рефлексів змін у ціннісних настановах сучасного нам суспільства, зроблене із залученням корпусних даних на матеріалі мов «середньоєвропейського стандарту», виявить основні риси нової концептуальної картини світу сучасності на підставі окреслення спільної для багатьох етносів (принаймні європейських) системи цінностей та антицінностей.

Мету проекту можна сформулювати як створення алгоритму аналізу процесу змін аксіологічних орієнтацій суспільства, який буде здійснений на матеріалі художніх та медіатекстів із залученням корпусного підходу до опрацювання мовно-мовленнєвих даних. Поставлена мета імплікує розв'язання таких завдань:

1) Проаналізувати і схарактеризувати основні наукові підходи до вивчення мови ЗМІ та постмодерного літературного тексту в міждисциплінарному аспекті на перетині ідей, що сформувалися у сучасній лінгвокультурології, лінгвокогнітології, медіалінгвістиці, політичній лінгвістиці, філософії, герменевтиці, літературознавстві.

2) Вивчити соціальні, політичні, економічні, психологічні, лінгвістичні та інші фактори впливу на сучасну людину в аспекті змін аксіологічних констант в іiі сприйнятті дійсності та виформовування нової постмодерної картини світу.

3) Визначити універсальні, а також національно-специфічні для окремих культур аксіологічні домінанти на матеріалі сучасних офіційних (газети, журнали, комерційні сайти) та неофіційних (інтернет-блоги, чати, дискусії, форуми) інтернет-ресурсів із 
урахуванням фундаментальних змін в аксіосфері суспільства, які відбулися протягом останніх 10-15-ти років; розробити їх типологію.

4) Опрацювати інтегрований підхід до аналізу мови 3МI та постмодерного літературного тексту, який передбачав би виділення вербально-невербальних маркерів ціннісних домінант на основі застосування лінгвоінформаційних технологій ментально-мовної кластеризації текстів корпусів мов та їх лінгвістичної експертизи.

Актуальність такого роду дослідження зумовлена повною відсутністю системних досліджень у заявленій площині як на вітчизняних теренах, так і за кордоном, адже наразі не існує розвідок, у рамках яких була б зроблена спроба дослідити зміни в аксіосфері сучасного суспільства на матеріалі багатьох європейських мов із залученням корпусного підходу до опрацювання мовно-мовленнєвих даних i виділення при цьому як глобальних, так i національно-специфічних цінностей, притаманних окремим лінгвокультурам.

В основу цього дослідження буде покладено антропоцентричний підхід як скерований на людину та прагматику їі життя, а також комплекс неолінгвістичних підходів до тлумачення лексико-фразеологічних та лексико-граматичних інновацій у медіа, які розглядатимуться під лінгвокогнітивним, лінгвокультурологічним, лінгвопрагматичним, дискурсивним, сугестивним кутами зору. Базою для здійснення всіх вище зазначених підходів виступатимуть лінгвоінформаційні технології корпусів опрацьовуваних мов. Щодо матеріалів КУМ (Корпусу української мови), на його основі буде здійснено ментально-мовну кластеризацію текстів Корпусу, лінгвістичну параметризацію як підгрунтя для експертизи будь-якого тексту, на основі чого будуть інтерпретовані результати лінгвістичної експертизи. Такого роду підхід ще ніколи не опробовувався 3 метою дослідження мовних рефлексів аксіологічних зсувів у свідомості різних етносів. Кінцевою метою проекту буде створення цілісного дослідницького діахронно заангажованого фрейму у царині опрацювання мовно-мовленнєвих проекцій динаміки змін аксіологічних констант, досліджуваних на матеріалах корпусів мов.

Дослідницький проект [Исследовательский проект]

() Голубовська І. О., Дарчук Н. П., Черненко А. А. [Голубовская И. А., Дарчук Н. П., Черненко А. А.], igolubovska777@gmail.com,nataliadarchuk@gmail.com, hanna.chernenko@gmail.com Мова і дискурсивні практики світового медіапростору у контексті змін аксіологічних домінант [Язык и дискурсивные практики мирового медиапространства в контексте изменений аксиологических доминант] (Українською / На укр. яз) 
Для здійснення проекту будуть застосовуватися описовий, порівняльний, зіставно-типологічний, таксономічний методи; методи аналізу, синтезу, індукції, дедукції; методи структурно-семантичного аналізу слова: компонентний та контекстуальний аналіз, трансформаційний метод, функціонально-стилістичний метод, метод безпосередніх складників та дерев залежностей, кількісно-якісного аналізу, статистичного аналізу; методи, що постали у новітній час: метод дискурсаналізу та метод контент-аналізу, прототипічний аналіз, метод концептуального аналізу, фреймового / гештальт-аналізу, конверсаційного, прагматичного та текстологічного аналізу, лінгвокультурологічної інтерпретації, внутрішньої інтроспекції; комплекс медіалінгвістичних методів - медіапланування, медіамоніторингу, медіафреймінгу та ін.

У рамках проекту планується: 1) розробити методику лінгводеконструкції вербалізованих аксіологічних структур, що надасть можливість оприявнювати приховані ціннісні настанови мовця та його наміри впливати на аксіологічні уподобання адресата, розпізнавати способи такого впливу, реалізовані на різних рівнях мовної системи і тексту; 2) віднайти закономірності впливу мас-медійних та художніх текстів на процес трансформації аксіологічних домінант світової та української громади; 3) відстежити новації у розвитку національних систем мов (поява нових лексичних та фразеологічних одиниць неолексем і неофразем); 4) установити напрямки зміни мовної норми під впливом узуально-оказіональних використань; 5) розробити програмне забезпечення для автоматичної лінгвістичної експертизи текстів, яка надаватиме досліднику повну інформацію про текст, висвітлюючи його аспекти: функціональний (оцінка за вживаністю); синтагматичний (сполучуваність - оцінюється за якісними та кількісними ознаками; Lграми); епідигматичний (оцінювання за кількістю значень словникових одиниць); парадигматичний (входження словникових одиниць до різних лексичних парадигм); хронологічний (накопичена частота вживаності лексем у певний часовий період).

Очікувані результати спиратимуться передусім на спостереження за семіотичною реальністю мовного узусу, представленого у світовому та українському медіа- та художньому просторі, результати чого будуть 
піддані багатоаспектному мовознавчому аналізу із залученням статистичних даних електронних корпусів мов (англійської, німецької, української та інших). Першочерговим завданням у цій царині можна вважати розроблення способів фіксації культурно та ціннісно маркованих мовно-мовленнєвих одиниць різного рівня абстракції.

Наразі не існує досліджень, у рамках яких було б зроблено спробу дослідити зміну аксіосфери сучасного суспільства на матеріалі декількох мов із залученням корпусного підходу до опрацювання мовномовленнєвих даних із подальшим виділенням як універсальних, так i національно-специфічних цінностей, притаманних окремим лінгвокультурам. I хоча вплив суспільства на розвиток мови в лінгвістиці висвітлюється 3 початку 2000-х рр. [Блакар 1987; Кудрявцева, Дядечко, 2005], це робилося переважно соціологами, які досліджували ціннісні аспекти такого впливу, звертаючись до кількісних методів, передусім контент-аналізу. Філологи ж $з$ пропозицією якісного аналізу семантики мовних та мовленнєвих одиниць все ще залишаються на маргінесах. Так, запропонований О. О. Тараненком [Тараненко 2012-2014] аналіз формування аксіологічних пріоритетів українського суспільства не охоплює тих процесів, що відбуваються за межами українського інформаційного простору; окрім того, автор зосереджується переважно на словотвірних аспектах мовного буття, - водночас у пропонованому дослідженні передбачено охопити різні рівні мовного аналізу, починаючи від морфолого-лексичного аж до рівня семантики тексту та метадискурсу. Праця Р. Джекендоффа [Jackendoff 2001] розкриває структуру ціннісного концепту, але не дає уявлення про динаміку його формування й трансформації, зокрема у взаємозв'язку з іншими мовними процесами, що відбуваються у медіапросторі. Пропоноване дослідження якраз зосереджено на з'ясуванні специфіки моделей аксіологічних трансформацій, які відбуваються у просторі сучасних медіа. Окрім того, давно вже виникла нагальна потреба опробовування методу критичного дискурс-аналізу у царині мовознавства [Wodak, Meyer 2009].

Новизна методики автоматизованої лінгвістичної експертизи тексту, яка покликана забезпечити автоматичну обробку частини даних та їхній статистичний аналіз, зумовлена тим, що сучасні корпуси мов часто-густо

Дослідницький проект [Исследовательский проект]

(С) Голубовська І. О., Дарчук Н. П., Черненко А. А. [Голубовская И. А., Дарчук Н. П., Черненко А. А.], igolubovska777@gmail.com,nataliadarchuk@gmail.com,hanna.chernenko@gmail.com

Мова і дискурсивні практики світового медіапростору у контексті змін аксіологічних домінант [Язык и дискурсивные практики мирового медиапространства в контексте изменений аксиологических доминант] (Українською / На укр. яз) 
не дають можливості отримати інформацію про граматичні та семантичні особливості аналізованого тексту (див. альтернативні корпуси української мови он-лайн: korpus.org.ua/search/; Проект групи Lang-Ukr. URL: http://lang.org.ua/uk/; General Regionally annotated Corpus of Ukraine. URL: http://uacorpus.org/; Корпуси текстів української мови ДонНУ. URL: corpora.donnu.edu.uа та ін.).

Очікувані результати можуть суттєво вплинути на розширення можливостей саморефлексії людини у контексті оприявнення аксіологічних настанов, які мовці умисно чи мимохіть транслюють у своій повсякденній комунікації (багато 3 них формують саме медіа- та художні тексти). Це вкрай важливо в умовах інформаційної, консцієнтальної війни, коли існує потреба у підвищенні рівня критичного сприйняття масмедійних текстів, які дуже часто виступають знаряддям політичної пропаганди. Так само нагальною $є$ потреба розуміння, які саме засоби використовують авторитетні мовці для формування певної ціннісної ієрархії суспільства; діагностування аксіологічних змін на рівні функціонування медіадискурсу в період активізації глобалізаційних процесів, коли стикаються та перетинаються різні системи цінностей. Особливої актуальності зміна ціннісної шкали набуває у наш час, коли відбувається бурхливий розвиток української нації як особливої спільноти зі своєю мовно-культурною ідентичністю і своєю системою традиційних цінностей. Примат ідеального на матеріальним, який зумовлює наукову й концептуальну картини світу сучасності, фактично ставить економічний успіх країни в залежність від тих аксіологічних домінант гуманітарної сфери, які вже довели свою ефективність на прикладі розвинених європейських країн та США.

Результати планованого дослідження нададуть можливість запропонувати цілісне бачення мовних та дискурсивних процесів, що відбуваються в сучасному світовому та українському медіапросторі під впливом аксіологічних змін. Вироблення необхідних методів та методик дослідження цих процесів, зокрема автоматизованої експертизи текстів, аксіологічної лінгводеконструкції, діахронного моделювання аксіологічних мовних змін тощо суттєво збагатить методологометодичний апарат сучасного мовознавства та гуманітарних наук у 
цілому, що $є$ конче необхідним для дослідження цілого комплексу актуальних на сьогодні проблем конструювання ідентичності, міжкультурної комунікації, 3'ясування специфіки мови ворожнечі, осмислення тоталітарного та колоніального минулого країн пострадянського простору, і не тільки.

Висновки щодо особливостей відображення в мові аксіологічних домінант, які виформовують світоспоглядання сучасної людини, їх впливу на становлення нового формату громадянського суспільства, стануть логічним продовженням сучасних напрацювань у царині мовної семантики, лінгвоконцептології, прагмалінгвістики, корпусної лінгвістики, піднімаючи філологічні напрацювання сьогодення на якісно новий рівень усвідомлення та узагальнення у контексті потреб саморефлексії людства у цілому.

\section{Література:}

1. Арутюнова, Н. Д. Язык и мир человека (Москва, Языки русской культуры, 1999), 896.

2. Бєссонова, О. Л. «Оцінний тезаурус англійської мови: когнітивний i гендерний аспекти.» Автореф. дис. д-ра філол. наук, Київ, 2003.

3. Блакар, Р. М. «Язык как инструмент социальной власти.» Язык $u$ моделирование сочиального взаимодействия, сост.В.М.Сергеева и П. Б. Паршина; общ. ред. В. В. Петрова (Москва, Прогресс, 1987): 88-125.

4. Водак, Р. «Взаимосвязь «дискурс - общество»: когнитивный подход к критическому дискурс-анализу.» Современная политическая лингвистика, Э. В. Будаев, А. П. Чудинов (Екатеринбург, 2006): 123-136.

5. Водак, Р. «Критическая лингвистика и критический анализ дискурса.» Политическая лингвистика 4 (38) (2011): 286-291.

6. Вригт, Г. Х. фон. Логико-философские исследования: избранные труды, пер. с англ. Е. И. Тарусина, А. С. Карпенко и др.; общ. ред. Г. В. Рузавина, В. А. Смирнова (Москва, Прогресс, 1986), 600.

7. Вольф, Е. М. «Оценочное значение и соотношение признаков «хорошо» / «плохо».» Вопросы языкознания 5 (1986): 98-106.

8. Голубовська, І. О. «Мова соціальних мереж як новітній лінгвістичний феномен.» Мовні і концептуальні картини світу 55 (2) (2015): 49-56.

9. Голубовська, І. О., Клименко, Л. В., Левко, О. В., Гудзенко, О. П., Александрова, Г. А., Черненко, А. А. Концепти $i$ концептосфери: динамічні виміри:

Дослідницький проект [Исследовательский проект]

() Голубовська І. О., Дарчук Н. П., Черненко А. А. [Голубовская И. А., Дарчук Н. П., Черненко А. А.], igolubovska777@gmail.com,nataliadarchuk@gmail.com,hanna.chernenko@gmail.com

Мова і дискурсивні практики світового медіапростору у контексті змін аксіологічних домінант [Язык и дискурсивные практики мирового медиапространства в контексте изменений аксиологических доминант] (Українською / На укр. яз) 
колективна монографія, під ред. І. О. Голубовської, Л. В. Клименко (Київ, Логос, 2017), 178.

10. Голубовська, I. O, Орлова, Т. В. Політичний дискурс як інструмент маніпулювання свідомістю електорату (на матеріалі інавгураційної промови Дональда Трампа 20 січня 2017 р.).» Studia Linguistica 11 (2017): 9-29.

11. Голубовська, I. О., Черненко, Г. А. «Фреймове моделювання концепту ДОБРОЧЕСНІСТЬ: зіставний аспект.» Мовознавство 1 (2017): 3-12.

12. Дарчук, Н. П. «Корпус текстів Тараса Шевченка як джерело для мовознавчих студій.» Science and Education: A New Dimension. Philology 32, Issue 122 (Budapest, 2017): 33-38.

13. Дарчук, Н. П. «Компьютерная грамматика украинского языка АГАТ и перспективы ее использования.» Актуальные проблемы современной прикладной лингвистики 37 (Минск, 2017): 37-43.

14. Дарчук, Н. П., Алексієнко, Л. А. «Автоматичне конструювання частотного словника сполучуваності української мови.» Сучасна україністика: Проблеми мови, літератури і культури. Оломоуцький симпозіум украӥністів (Оломоуць, 2016): 33-38.

15. Жаботинская, С. А. «Язык как оружие в войне мировоззрений. Майдан Антимайдан : словарь-тезаурус лексических инноваций : Украина, декабрь 2013 декабрь 2014.» Интернет-издание (Киев, Укр. асоц. когнітивної лінгвістики і поетики, 2015), доступ http://uaclip.at.ua/zhabotinskaja-jazyk_kak_oruzhie.pdf (дата обращения: 30.01.2018).

16. Ивин, А. А. Аксиология (Москва, Высш. шк., 2006), 390.

17. Клименко, Л. В. «Семантичний простір фланерства у французькій лінгвокультурі.» Science and Education a New Dimension. Philology 31 (V), Issue 118 (Budapest, 2017): 33-36.

18. Кудрявцева, Л. О., Дядечко Л. П., Дорофєєва О. М., $\quad$ Черненко Г. А., Філатенко І. О. «Сучасні аспекти дослідження мас-медійного дискурсу: експресія вплив - маніпуляція.» Мовознавство 1 (2005): 58-66.

19. Levko, O. «Somatic means of emotion verbalization in Ancient Greek and Ukrainian linguocultures.» Science and Education: A New Dimension. Philology 26 (IV), Issue 106 (Budapest, 2016): 30-33.

20. Левко, О. «Діахронні виміри вербалізації концептів ПРАВЕДНІСТЬ і $\triangle \mathrm{IKAIO \Sigma YNH} \mathrm{в} \mathrm{українській} \mathrm{мові} \mathrm{та} \mathrm{грецькій} \mathrm{мові} \mathrm{Нового} \mathrm{Завіту:} \mathrm{точки} \mathrm{перетину.»}$ Studia linguistica 9 (2016): 54-63.

21. Лингвистика и аксиология. Этносемиометрия ценностных смыслов: коллективная монография, Е. Ф. Серебренникова, Н. П. Антипьев, Л. Г. Викулова и др. (Москва, Тезаурус, 2011), 352.

22. Сизонов, Д. Ю. «Психолінгвістичні основи медіаграмотності: до проблеми інтерпретації медіатекстів.» Science and education 7 (2017): 82-88.

23. Тараненко, О.О. «Українська мова і сучасна мовна ситуація в Україні.» Мовознавство 4 (2001): 3-19.

Research Project [Doslidnyc'kyj proekt]

(C) Golubovska I., Darchuk N., Chernenko H. [Golubovs'ka I. O., Darchuk N. P., Chernenko A. A.], igolubovska777@gmail.com,nataliadarchuk@gmail.com, hanna.chernenko@gmail.com

Language and Discourse Practices of World Media in the Context of Axiological Dominants' Change [Mova i dyskursyvni praktyky svitovogo mediaprostoru u konteksti zmin aksiologichnyh dominant] (in Ukrainian) 
24. Тараненко, О. О. «Формування нової системи соціальних цінностей i пріоритетів українського суспільства (на матеріалі української мови кінця $\mathrm{XX}$ - початку XXI ст.).» Мовознавство (2012), № 3: 3-31; № 5: 13-40; № 6: 3-22 ; (2013), № 6: 3-26 ; (2014), № 1: 3-31; № 3: 3-33; № 5: 14-34.

25. Харитонова, Д. Д. «Реалізація дихотомії «свій $\leftrightarrow$ чужий» у політичному дискурсі (на матеріалі виступу в суді Ю. В. Тимошенко).» Науковий вісник Міжнародного гуманітарного університету, Серія: Філологія 27, т 1 (Одеса, 2017): 154-157.

26. Шевченко, Л. І. «Медіалінгвістика в сучасній Україні: аналіз ситуації.» Актуальні проблеми украӥнської лінгвістики:теорія і практика 26 (2013): 3-12.

27. Черненко, А. А. Мовленнєвий вплив на ціннісні системи: діапазон імовірностей (Київ, Видавничий дім «Дмитра Бураго», 2018), 404.

28. Яворська, Г. М. «До проблеми формування європейської ідентичності в Україні.» Наукові записки Інституту політичних $і$ етнографічних досліджень ім. I. Ф. Kураса 42 (2008): 269-277.

29. Bartmiński, J. «Projekt i założenia ogólne słownika aksjologicznego.», [w:] Język a Kultura, t. 2, red. Jerzy Bartmiński, Jadwiga Puzynina (Wrocław, 1989): 293-312.

30. Golubovska, I. «Lingual Concept: Epistemic Approaches in Modern Ukrainian Linguistics.» Науковий вісник Міжнародного гуманітарного університету, Серія: Філологія 27, т. 1 (Одеса, 2017): 128-132.

31. Fairclough, N. Discourse and SocialChange (Cambridge, PolityPress, 1992), 259.

32. Fairclough, I. \& Fairclough, N. Political Discourse Analysis. A Method for Advanced Students (London, Routledge, 2012).

33. Jackendoff, R. «The peculiar logics of Value.» Journal of Cognition and Culture 34 (2001): 375-407.

34. Wodak, R., Meyer, M. Critical discourse analysis: history, agenda, theory, and methodology. Methods for Critical Discourse Analysis, ed. by Wodak, Ruth (London, Sage, 2009): 1-33.

\section{References}

1. Arutjunova, N. D. Jazyk i mir cheloveka (Moskva, Jazyki russkoj kul'tury, 1999), 896.

2. Bjessonova, O. L. «Ocinnyj tezaurus anglijs'koi' movy: kognityvnyj i gendernyj aspekty.» Avtoref. dys. d-ra filol. nauk, Kyi'v, 2003.

3. Blakar, R. M. «Jazyk kak instrument social'noj vlasti.» Jazyk i modelirovanie social'nogo vzaimodejstvija, sost. V. M. Sergeeva i P. B. Parshina; obshh. red. V. V. Petrova (Moskva, Progress, 1987): 88-125.

Дослідницький проект [Исследовательский проект]

(С Голубовська І. О., Дарчук Н. П., Черненко А. А. [Голубовская И. А., Дарчук Н. П., Черненко А. А.], igolubovska777@gmail.com, nataliadarchuk@gmail.com, hanna.chernenko@gmail.com

Мова і дискурсивні практики світового медіапростору у контексті змін аксіологічних домінант [Язык и дискурсивные практики мирового медиапространства в контексте изменений аксиологических доминант] (Українською / На укр. яз) 
4. Vodak, R. «Vzaimosvjaz' «diskurs - obshhestvo»: kognitivnyj podhod k kriticheskomu diskurs-analizu.» Sovremennaja politicheskaja lingvistika, Je. V. Budaev, A. P. Chudinov (Ekaterinburg, 2006): 123-136.

5. Vodak, R. «Kriticheskaja lingvistika i kriticheskij analiz diskursa.» Politicheskaja lingvistika 4 (38) (2011): 286-291.

6. Vrigt, G. H. fon. Logiko-filosofskie issledovanija: izbrannye trudy, per. s angl. E. I. Tarusina, A. S. Karpenko i dr.; obshh. red. G. V. Ruzavina, V. A. Smirnova (Moskva, Progress, 1986), 600.

7. Vol'f, E. M. «Ocenochnoe znachenie i sootnoshenie priznakov «horosho» / «ploho».» Voprosy jazykoznanija 5 (1986): 98-106.

8. Golubovs'ka, I. O. «Mova social'nyh merezh jak novitnij lingvistychnyj fenomen.» Movni i konceptual'ni kartyny svitu 55 (2) (2015): 49-56.

9. Golubovs'ka, I. O., $\quad$ Klymenko, L. V., $\quad$ Levko, O. V., $\quad$ Gudzenko, O. P., Aleksandrova, G. A., Chernenko, A. A. Koncepty i konceptosfery: dynamichni vymiry: kolektyvna monografija, pid red. I. O. Golubovs'koi', L. V. Klymenko (Kyi'v, Logos, 2017), 178.

10. Golubovs'ka, I. O, Orlova, T. V. P»olitychnyj dyskurs jak instrument manipuljuvannja svidomistju elektoratu (na materiali inavguracijnoi' promovy Donal'da Trampa 20 sichnja 2017 r.).» Studia Linguistica 11 (2017): 9-29.

11. Golubovs'ka, I. O., Chernenko, G. A. «Frejmove modeljuvannja konceptu DOBROChESNIST": zistavnyj aspekt.» Movoznavstvo 1 (2017): 3-12.

12. Darchuk, N. P. «Korpus tekstiv Tarasa Shevchenka jak dzherelo dlja movoznavchyh studij.» Science and Education: A New Dimension. Philology 32, Issue 122 (Budapest, 2017): 33-38.

13. Darchuk, N. P. «Komp'juternaja grammatika ukrainskogo jazyka AGAT i perspektivy ee ispol'zovanija.» Aktual'nye problemy sovremennoj prikladnoj lingvistiki 37 (Minsk, 2017): 37-43.

14. Darchuk, N. P., Aleksijenko, L. A. «Avtomatychne konstrujuvannja chastotnogo slovnyka spoluchuvanosti ukrai'ns'koi' movy.» Suchasna ukrai'nistyka: Problemy movy, literatury i kul'tury. Olomouc'kyj sympozium ukrai'nistiv (Olomouc', 2016): 33-38.

15. Zhabotinskaja, S. A. «Jazyk kak oruzhie v vojne mirovozzrenij. Majdan Antimajdan : slovar'-tezaurus leksicheskih innovacij : Ukraina, dekabr' 2013 - dekabr' 2014.» Internet-izdanie (Kiev, Ukr. asoc. kognitivnoï lingvistiki i poetiki, 2015), dostup http://uaclip.at.ua/zhabotinskaja-jazyk_kak_oruzhie.pdf (data obrashhenija: 30.01.2018).

16. Ivin, A. A. Aksiologija (Moskva, Vyssh. shk., 2006), 390.

17. Klymenko, L. V. «Semantychnyj prostir flanerstva u francuz'kij lingvokul'turi.» Science and Education a New Dimension. Philology 31 (V), Issue 118 (Budapest, 2017): 33-36.

18. Kudrjavceva, L. O., $\quad$ Djadechko, L. P., $\quad$ Dorofjejeva, O. M., Chernenko, G. A., Filatenko I. O. «Suchasni aspekty doslidzhennja mas-medijnogo dyskursu: ekspresija vplyv - manipuljacija.» Movoznavstvo 1 (2005): 58-66.

Research Project [Doslidnyc'kyj proekt]

(C) Golubovska I., Darchuk N., Chernenko H. [Golubovs'ka I. O., Darchuk N. P., Chernenko A. A.], igolubovska777@gmail.com,nataliadarchuk@gmail.com,hanna.chernenko@gmail.com

Language and Discourse Practices of World Media in the Context of Axiological Dominants' Change [Mova i dyskursyvni praktyky svitovogo mediaprostoru u konteksti zmin aksiologichnyh dominant] (in Ukrainian) 
19. Levko, O. «Somatic means of emotion verbalization in Ancient Greek and Ukrainian linguocultures.» Science and Education: A New Dimension. Philology 26 (IV), Issue 106 (Budapest, 2016): 30-33.

20. Levko, O. «Diahronni vymiry verbalizacii' konceptiv PRAVEDNIST" i $\triangle \mathrm{IKAIO} \Sigma \mathrm{YNH}$ v ukrai'ns'kij movi ta grec'kij movi Novogo Zavitu: tochky peretynu.» Studia linguistica 9 (2016): 54-63.

21. Lingvistika i aksiologija. Jetnosemiometrija cennostnyh smyslov: kollektivnaja monografija, E. F. Serebrennikova, N. P. Antip'ev, L. G. Vikulova i dr. (Moskva, Tezaurus, 2011), 352.

22. Syzonov, D. Ju. «Psyholingvistychni osnovy mediagramotnosti: do problemy interpretacii' mediatekstiv.» Science and education 7 (2017): 82-88.

23. Taranenko, O. O. «Ukrai'ns'ka mova i suchasna movna sytuacija v Ukrai'ni.» Movoznavstvo 4 (2001): 3-19.

24. Taranenko, O. O. «Formuvannja novoi' systemy social'nyh cinnostej i priorytetiv ukrai'ns'kogo suspil'stva (na materiali ukrai'ns'koi' movy kincja $\mathrm{HH}$ - pochatku HHI st.).» Movoznavstvo (2012), № 3: 3-31; № 5: 13-40; № 6: 3-22; (2013), № 6: 3-26; (2014), № 1: 3-31; № 3: 3-33; № 5: 14-34.

25. Harytonova, D. D. «Realizacija dyhotomii' «svij ↔ chuzhyj» u politychnomu dyskursi (na materiali vystupu v sudi Ju. V. Tymoshenko).» Naukovyj visnyk Mizhnarodnogo gumanitarnogo universytetu, Serija: Filologija 27, t 1 (Odesa, 2017): 154-157.

26. Shevchenko, L. I. «Medialingvistyka v suchasnij Ukrai'ni: analiz sytuacii'.» Aktual'ni problemy ukrai'ns'koi' lingvistyky:teorija i praktyka 26 (2013): 3-12.

27. Chernenko, A. A. Movlennjevyj vplyv na cinnisni systemy: diapazon imovirnostej (Kyi'v, Vydavnychyj dim «Dmytra Burago», 2018), 404.

28. Javors'ka, G. M. «Do problemy formuvannja jevropejs'koi' identychnosti v Ukrai'ni.» Naukovi zapysky Instytutu politychnyh i etnografichnyh doslidzhen' im. I. F. Kurasa 42 (2008): 269-277.

29. Bartmiński, J. «Projekt i założenia ogólne słownika aksjologicznego.», [w:] Język a Kultura, t. 2, red. Jerzy Bartmiński, Jadwiga Puzynina (Wrocław, 1989): 293-312.

30. Golubovska, I. «Lingual Concept: Epistemic Approaches in Modern Ukrainian Linguistics.» Науковий вісник Міжнародного гуманітарного університету, Серія: Філологія 27, т. 1 (Одеса, 2017): 128-132.

31. Fairclough, N. Discourse and SocialChange (Cambridge, PolityPress, 1992), 259.

32. Fairclough, I. \& Fairclough, N. Political Discourse Analysis. A Method for Advanced Students (London, Routledge, 2012).

33. Jackendoff, R. «The peculiar logics of Value.» Journal of Cognition and Culture 3-4 (2001): 375-407.

34. Wodak, R., Meyer, M. Critical discourse analysis: history, agenda, theory, and methodology. Methods for Critical Discourse Analysis, ed. by Wodak, Ruth (London, Sage, 2009): 1-33.

Дослідницький проект [Исследовательский проект]

(С Голубовська І. О., Дарчук Н. П., Черненко А. А. [Голубовская И. А., Дарчук Н. П., Черненко А. А.], igolubovska777@gmail.com, nataliadarchuk@gmail.com, hanna.chernenko@gmail.com

Мова і дискурсивні практики світового медіапростору у контексті змін аксіологічних домінант [Язык и дискурсивные практики мирового медиапространства в контексте изменений аксиологических доминант] (Українською / На укр. яз) 